\title{
Reading backwards from the beginning: My life with the Psalter $^{1}$
}

\author{
N L de Claissé-Walford \\ (McAfee School of Theology)
}

\section{ABSTRACT \\ Reading backwards from the beginning: My life with the Psalter}

The Psalter is more than the sum of its individual parts. The book is indeed the collected hymns of ancient Israel and its designation as "the hymnbook of second temple period" is appropriate. But, in addition, the Psalter is a narrative within a poetic text. Contemporary interest in the Psalter includes the desire to flesh out, give breath to, and stir the nephesh ("the inmost being") of the text of the book of Psalms. But are scholars making any progress? In this article the author answers positively and is intended to provide a summary of this same learning experience.

Reading backwards from the beginning. How, precisely, does one do that? It sounds painful at the least, meaningless and unfruitful at the most. But what if we took a literary piece, say a book of the Bible, and read its beginning and then moved to its end and proceeded backward through it - seeking the meaning of the in-between from the way it ends and the way it begins?

I have spent the last fifteen years of my life studying the book of Psalms, the Psalter. W $\mathrm{H}$ Bellinger at Baylor University encouraged me to embark on a "close study" of the Psalter; a 1985 SBL Dissertation Series book entitled The Editing of the Hebrew Psalter gave me the direction in which my "close study" would travel. The author of that book was Gerald Henry Wilson (see Wilson 1985) ${ }^{2}$.

Gerald Wilson stands near the beginning of a movement in Psalm studies that suggests that the Psalter is more than the sum of

1 This paper was originally delivered as the Southeast Conference for the Study of Religion (SECSOR) presidential address in Atlanta, Georgia, in March of 2006.

2 Wilson died unexpectedly in November 2005 just before the national Society of Biblical Literature meeting in Philadelphia, Pennsylvania. This paper was dedicated to his memory. 
its individual parts (cf. Childs 1979) ${ }^{3}$. The book is indeed the collected hymns of ancient Israel and its designation as "the hymnbook of second temple period" is appropriate. But, in addition, the Psalter is a narrative within a poetic text. The hint of the story told by the Psalter was the gift that Gerald Wilson gave to us. And it has been the task of those of us who have studied the Psalter in the years since Wilson's groundbreaking work in the 1980s to flesh out, give breath to, and stir the nephesh ("the inmost being") of the text of the book of Psalms. And how have we fared?

I maintain that we have made great progress. What follows is a summary of what we have learned so far. The Psalter was most likely shaped into the form in which we have it in the Bible by the late-postexilic community. Careful study of its five-book structure suggests that it tells a story, that the Psalter is a connected narrative rather than a haphazard collection of songs from ancient Israel. And the story goes something like this. Psalms 1 and 2 introduce the major themes of the Psalter. In Psalm 1, the psalmist outlines two paths in life - the path of the wicked and the path of the righteous. Its opening words are "ashre (usually translated 'happy' or 'blessed', but better rendered 'content') is the person who does not follow the advice of the wicked". For, the wicked person is like chaff which the wind blows away, but the righteous person, through diligent mediation on the torah, the instruction of God, is like a tree firmly planted by a stream. Psalm 2 introduces the theme of royalty - for ancient Israel, royalty from the line of David, but in Psalm 2 the royal concept has an interesting twist: God, not humanity, ultimately determines who will be king and what role that king will play. Psalm 2 ends with the same word that begins Psalm 1- "ashre - content are the ones who take refuge in God”.

The remainder of Book One (Pss 3-41) and Book Two (Pss 4272) recount the history of ancient Israel during the time of the kingship of David, son of Jesse; Book Three (Pss 73-89) reflects the times of Solomon, the divided kingdoms, the fall of the Northern Kingdom to the Assyrians, and the fall of Jerusalem to the Babylonians; Book Four (Pss 90-106) addresses the Israelites in Exile in Babylon; and Book Five (Pss 107-150) recounts the return

3 The real beginning of the movement can be credited to Brevard S. Childs in his Introduction to the Old Testament as Scripture (Childs 1979). 
from Exile, the rebuilding of the Temple and life in postexilic Jerusalem - a life radically different from what it was before the Babylonian conquest.

The story of the Psalter seems to be a summons to the people of postexilic Israel to review their history, come to see that in their postexilic life setting having an earthly king of the line of David is no longer possible, and to acknowledge God as king and sovereign over Israel as a means for survival in their present circumstances and hope for the future. Just how God's kingship could and would be realized within the life of the postexilic community and beyond is one of the major issues confronting those of us who study the story of the Psalter today ${ }^{4}$.

Even so, with a few asides and room for scholarly idiosyncrasies, the big "story" — the metanarrative, if you will — of the Psalter seems agreed upon and psalm scholars are now spending more time focusing on the smaller units of shape within the Psalter - the so-called "local narratives" — the shaping of the five individual books which make up the Psalter and the shaping and connectedness of groups of psalms within those individual books.

Could we go too far? Could we come to the point where we have found connectednesses that are not there? Grasp at story-lines that simply don't exist? Yes. Of course. That is the danger of any intensive study of the biblical text. But we continue to study and wonder and ask, "What if?” But we continue on the quest.

The portion of the Psalter that has intrigued me most during the past five years has been Book Five, Psalms 107-150. Thomas W Mann, writes in reference to the shape of the Pentateuch, "The meaning of a story is often significantly determined by the way it ends” (Mann 1988:157). The Pentateuch ends with the death of Moses and the people camped outside the land of promise. I suggest that the way the Psalter ends, in Book Five, significantly determines the meaning of the entire Psalter, the meaning of the Psalter's story.

4 Some talk about a "democratization" of kingship; that is, the people of Israel must now be the hands and feet, the mouthpiece of God the king - thus all people are to seek the welfare of the community and the good of the nation, as we read in the words of Ps 72:2-4. Recently, another scholar suggested that rather than "democratization of kingship", we use the term "communitizing of kingship”. 
Recall that Book Five, according to the story-line which is suggested for the Psalter, recounts the return of the Israelites from Exile, the rebuilding of the Temple, and the shape of life in postexilic Jerusalem. What shape would that life take? How would it be ordered? Psalm 107, which opens Book Five, begins with the words:

O give thanks to the Lord, for he is good for his steadfast love endures forever.

Let the redeemed of the Lord say so, those he redeemed from trouble and gathered in from the lands, from the east and from the west, from the north and from the south. (Ps 107:1-3)

The psalm goes on to tell the story of God's saving acts on behalf of various groups of people. In verses 33-42, the psalmist proclaims the good provisions of God for the people, and the psalm closes with the words, "Let the one who is wise heed these words, and consider the steadfast love of the Lord” (Ps 107:43).

Book Five continues in Psalms 108-110 with three psalms attributed, in their superscriptions, to David. According to our "story" of the Psalter, David is very much out of place in this book, which recounts the second temple period of Israel's history. David ruled Israel some 500 years previously and a king of the line of David could no longer rule over Israel because Israel was vassal to a number of foreign powers: the Persians, the Greeks, and then the Romans.

The next psalm in Book Five, Psalm 111 is a compact alphabetic acrostic, employing only seventy-two words to convey its message of celebration for God's deeds on behalf of the covenant community. Psalm 111 begins with the words "Praise the Lord Hallelujah", words that occur some fifty-six times in Book Five.

Its closing verse is, "The beginning of wisdom is the reverence of the Lord, a good understanding comes to all who do it".

Psalm 112, clearly a partner to Psalm 111, is also a compact alphabetic acrostic, employing only seventy-nine words to convey its message: the community's response to God's deeds on behalf of the people. The opening verse of the psalm is "Hallelujah! ashre 
('happy' or 'content') is the one who reverences the Lord, in the Lord's commandments greatly delighting”.

Psalms 113-118 are known as the Egyptian Hallel psalms, a collection of psalms traditionally read during Passover, the Spring festival which commemorates and celebrates the Exodus from Egypt. Each of these psalms begins or ends with the words "Hallelujah".

Psalm 119, a massive alphabetic acrostic, follows the Egyptian Hallel psalms. Eight lines of the psalmic poem are given over to each letter of the Hebrew alphabet, yielding a 176-line text. The psalm celebrates the goodness of the Torah and of the one who keeps the Torah. It begins with the words, "Ashre are those whose way is blameless, who walk in the Torah of the Lord”. Psalm 119 is read at the Feast of Pentecost, the Spring festival observed fifty days after Passover. The Feast celebrates the giving of the Torah to Moses at Sinai during the Wilderness Wanderings.

Following Psalm 119 are a group of psalms, 120-134, which are described in their superscriptions as "Songs of Ascents". We may speculate that they are so-designated because of their frequent references to Jerusalem and Zion. The Songs of Ascents are the psalms traditionally read at the Autumn Feast of Tabernacles (or Booths, or Sukkoth). The Feast of Tabernacles commemorates God's care for the Israelites during the time of the Wilderness Wanderings, reinforcing the "pilgrimage" theme of the Songs of Ascents.

The Songs of Ascents is an interesting and varied collection, perhaps reflective of the many emotions that characterized the Israelites during their time in the wilderness. Psalm 127 is one of only two psalms in the Psalter that are ascribed, in their superscriptions to Solomon. Psalm 128 commences with the familiar word, ashre - "content is each one who reverences the Lord, who walks in his ways". Psalm 133 employs a simple proverbial saying from ancient Israel's social life - "Behold, how very good and pleasant it is when kindred live together in unity!"

Following the Songs of Ascents is Psalm 135, a hymn of the community which begins and ends with "Hallelujah", a phrase which reverberates throughout Book Five. Psalm 136, another community hymn, has at the end of each verse the refrain "for God's hesed ('steadfast love') endures forever", suggesting a liturgical use for the psalm. Psalm 137 is a heartfelt remembrance of the exile in 
Babylon. The disturbing words in verse 9 are difficult to maneuver, "ashre ('happy' or 'content') shall they be who take your little ones and dash them against the rock!"

In Psalms 138-143, we return to psalms of David. In hymnic songs and heartfelt laments, David gives thanks to God for God's steadfast love in Psalm 138; wonders at God's intimate knowledge of him in 139; pleads with God to deliver him from evildoers in 140 and 142; and prays for discerning speech and answered prayers in 141 and 143.

Psalm 144 returns to the theme of royalty to which we were introduced in Psalm 2. Recall that the "royal theme" in Psalm 2 has an interesting twist: its message is that God ultimately determines who will be king and it ends with the words, "ashre (content) are the ones who heed these words”. In the royal Psalm 144, David says:

Blessed be the Lord, my rock, who trains my hands for war, and fingers for battle; but says in verse 3-4:

O Lord, what are human beings (adam) that you regard them, or mortals (ben enosh) that you think of them?

Human beings (adam) are like a breath; their days a passing shadow.

Psalm 144 ends in verse 15 with the now-familiar words:

ashre (content) are the people to whom such blessing falls;

ashre (content) are the people whose God is the Lord.

The next psalm, Psalm 145 is a fascinating, rich psalm. Its superscription attributes it to David (and thus the Psalter ends with eight psalms of David). It is an alphabetic acrostic, and its opening words are:

5 J Clinton McCann, Jr., offers, perhaps, the best understanding of these difficult words: "The worst possible response to monstrous evil is to feel nothing. What must be felt - by the victims and on behalf of the victims - are grief, rage, outrage. In the absence of these feelings, evil becomes an acceptable commonplace. In other words, to forget it to submit to evil, to wither and die; to remember is to resist, to be faithful, and to live again" (McCann 1996:28). 
I will extol you, my God and King, and bless your name forever and ever.

Every day I will bless you, and praise your name forever and ever.

The psalm begins with David and moves from his blessing and praise of the Lord as king, to the praise of all of the covenant community, to verse 21's proclamation:

My mouth will speak the praise of the Lord, and all flesh will bless his holy name forever and ever.

But the centerpiece, the highlight of Psalm 145, is found within its acrostic structure. The Hebrew word for king is melek. The consonants of that word are mem lamed kaf, the precursors of our own alphabet's $\mathrm{m}, \mathrm{l}$, and $\mathrm{k}$, which when reversed, render them in alphabetic order, kaf, lamed, mem, or “k, l, m”.

In the kaf, lamed, mem alphabetic lines (vss. 11-13) of Psalm 145, the Hebrew word for kingdom, which, is formed from the Hebrew root letters mem, lamed, kaf ( $m l k)$, is repeated three times:

They shall speak of the glory of your kingdom, and tell of your power,

to make known to all people your mighty deeds, and the glorious splendor of your kingdom.

Your kingdom is an everlasting kingdom, and your dominion endures throughout all generations.

I suggest that in Psalm 145, we witness a very clever scribe using words and form to emphasize David's acknowledgement of the kingship of God over Israel in the postexilic life situation. David celebrates God as king, and all of the covenant community and, indeed, all of creation can and must join in.

Psalms 146-150, the final doxological words of the Psalter, continue the Hallelujah's typical of Book Five and bring the Psalter to its climax with Psalm 150's proclamation:

Let everything that breathes praise the Lord!

Praise the Lord!

We come to the end. What can we posit in answer to the question, "How does the Psalter end?" What, indeed, can we tell about the meaning of the entire story of the Psalter by the way it ends - with 
reference to its beginning? I suggest that Book Five of the Psalter evinces strong evidence of what I will call "wisdom shaping”.

But, before we can adequately assess this statement, we must address a much more basic question. What do we mean by wisdom in the Hebrew Bible? Most of us associate wisdom with the book of Proverbs; and wisdom turned upside down with the book of Job. But how do we define it? The question actually comes in two parts. First is the issue of content. What are the topics addressed by the wisdom writers? Second is the issue of form. What literary forms are used by the wisdom writers to convey their messages?

First the issue of content. Kathleen O'Connor writes that "wisdom is a fluid, mercurial term, difficult to pin down or to contain within set parameters". But:

the Hebrew and Greek terms hokmah and sophia refer to a way of thinking, to a way of living . . . to a search for meaning and order, to sagacity about life and human relations akin to "common sense", to reverent "fear of the Lord", and, not least, to a woman, personified Wisdom herself. In its broadest sense wisdom is an approach to reality, an ethos which shares a set of ideas, assumptions and expectations about life (O’Connor 1988:23).

In summary, then wisdom is "a way of thinking, an approach to reality, a shared ethos, assumptions and expectations about life". But, what way of thinking? What assumptions and expectations?

Roland Murphy, in his 1990 book, The Tree of Life, points out that a "striking" characteristic of biblical wisdom literature is that "There is no mention of the promises to the patriarchs - the ancestors, the Exodus and Moses, the covenant and Sinai, the promise to David (2 Sam 7), and so forth". Wisdom does not represent the actions of God in Israel's history; it deals with daily human experience in the good world created by God" (Murphy 1990:1).

So, according to Murphy, wisdom has to do with understanding "daily human experience in the good God-created world", and largely disregards the story of God with the people of Israel. Is that the approach to reality, the way of thinking espoused by wisdom literature? Yes — and no. 
In the book of Proverbs, we encounter many times the words "the fear of the LORD is the beginning of wisdom". At the end of the musings of Qoheleth over the meaning of life, we find the words: "The end of the matter; all has been heard. Fear God, and keep his commandments; for that is the whole duty of each person”. Common sense - right conduct in daily human experience — or the fear of the Lord and the keeping of the commandments - or is there a difference?

Indeed, Murphy observes a change, a movement, in the focus of wisdom writing in the early second-century BCE Wisdom of Ben Sirach and the first-century CE Wisdom of Solomon. And I would add that we observe a similar change in the book of Baruch, which was composed in either the second or first century BCE. The Wisdom of Ben Sirach chapters 44-50 recount the history of Israel from the primeval stories of Genesis 1-11 to the reestablishment of temple worship in the postexilic period. At the end of chapter 50, we find these words:

Makarios (content) are those who concern themselves with these things and those who lay them to heart will become wise.

And in chapter 19, verse 20, Ben Sirach states, "The whole of wisdom is fear of the Lord, and in all wisdom there is the fulfillment of the law (in Greek, o nomos. in Hebrew, hatorah, 'the instruction')".

The book of Baruch states,

This is our God; none other can be compared to him.

He found the whole way to knowledge,

and gave wisdom to his servant Jacob

and to Israel, whom he loved.

Afterward she appeared on earth and lived with humankind.

She is the book of the commandment of God,

the law that endures forever.

All those who hold her fast will live,

and those who forsake her will die (3:36-1:1).

I suggest, then, that the "wisdom movement" of ancient Israel underwent a shift from wisdom as an approach to reality which relied primarily on axioms from everyday life and that did not incorporate the broad sweep of the history of ancient Israel - to wisdom as an aspect of reality that embraced the story of God's 
dealing with the people of Israel through time as a path to right living. And a major element of that story was living in a way that concretely embodied the instruction of God found in Torah, what has come to be known as "Torah Piety".

Thus we move to the second question, the question of the form of wisdom literature. James Crenshaw, in his Old Testament Wisdom: An Introduction, analyzes wisdom literature's form in the following way: "Wisdom consists of proverbial sentence or instruction, debate, and intellectual reflection" (Crenshaw 1981:19) — the larger literary forms reflected in Proverbs, Job, and Qoheleth. But what else might constitute the "form" of wisdom literature. Are there wisdom "words"? Words that signal that what one is about to hear is wisdom instruction? Are there wisdom "structures"? Structures in literature that signal that what one is about to read is wisdom instruction?

One word that is widely accepted as a "wisdom word" is, in Hebrew, ashre. The word appears some twenty-six times in the Psalter, and is especially prominent in Books One and Five. As we have seen, the word frames the introductory psalms of the Psalter, appearing at the beginning of Psalm 1, with "ashre (content) is the one who does follow the advice of the wicked" and at the end of Psalm 2, "ashre (content) is everyone who takes refuge in God". It appears six more times in Book One, culminating in the last psalm in Book 1, Psalm 41, verse 1 with: "ashre (content) is the one who considers the weak. ..”.

Ashre also occurs eleven times in Book Five of the Psalter. We recall Psalm 112's "ashre (content) are those who fear the LORD, who greatly delight in his commandments". In Psalm 119, we find, "ashre (content) are those whose way is blameless, who walk in the law of the LORD”. And Psalm 144 closes with two ashre statements:

Ashre (content) are the people to whom such blessing falls; ashre (content) are the people whose God is the Lord.

A wisdom word, prominent in the end and beginning of the Psalter.

While some disagree, I suggest that an important wisdom "structure" is the acrostic, a literary device in which each unit of a poetic composition begins with a successive letter of the Hebrew alphabet. Acrostic poems occur in six psalms in the Psalter, two in Book One and four in Book Five. We have posited, a la Kathleen O'Connor, that wisdom writers were concerned with "meaning and 
order" in life. Anthony Ceresko, in an essay titled "The Sage in the Psalms”, writes:

For psalmic wisdom, one way in which this concern with order expresses itself concretely, indeed, visually, is in its employment of the acrostic. One of the functions of this convention is to underline the sense of order and symmetry that the psalmist attempts to bring to the subject matter of the poem (Ceresko 1990:224-225).

Ceresko notes that Psalm 119 "with its predictable and orderly movement, serves to reinforce the psalms' message "that life is reliable and utterly symmetrical when the torah is honored" (Ceresko 1990:224-225). We may also read the alphabetic acrostic as a metaphoric device, signaling the reader/hearer that the subject matter being addressed by the acrostic poem has been summed up from A to $\mathrm{Z}$, from aleph to tav. Nothing more need or can be said on the matter.

And so, to recap: 1) Wisdom developed in ancient Israel from a common-sense approach to life into the concept of the fear of the Lord and then into wisdom being equated with what has come to be known as Torah Piety; 2) Wisdom language - in the case of the Psalter, the word ashre - is a clue to the reader/hearer to watch for wisdom instructions; and 3) The acrostic is a wisdom form that conveys a sense of orderliness, and indeed completeness, in life.

If these statements are true, then might we posit that the Psalter evidences a shaping that is reflective of a postexilic wisdom movement? The introductory psalms of the Psalter, the first (Ps 1) a psalm that celebrates the Torah, the second (Ps 2) a psalm about Israel's royal heritage, are framed by the wisdom word ashre (Ps 1:1 and Ps 2:11). The story of the Psalter begins with the reign of king David, moves through the stories of the divided kingdom, the fall of the Northern Kingdom, the destruction of Jerusalem, the exile in Babylon, and ends with the return from exile and the rebuilding of the Temple. Alongside the storyline is an accompanying search for meaning and order, for an approach to reality, for an ethos, for assumptions and expectations about life in an ever-changing world. And the answer is found, perhaps, in Book Five - an answer which echoes the introductory psalms of Book One. The opening psalm of Book Five ends with the words, "Let the one who is wise heed these things and consider the steadfast love of the Lord" (Ps 107:43). Then 
David appears in the following Psalms 108-110. David, who is no longer king over Israel and who has no real hope of a king of his line ever sitting upon the throne of Israel, leads the people in hallelujahs and festal celebrations of God, culminating in Psalm 145's acrostic celebration of God as king over David, over the covenant community, and over all creation.

Why a wisdom shaping? I'm not entirely sure how to argue for this any more than one might argue for any other ideological influence on the book of Psalms. I do think the wisdom evidence is worth considering. In the absence of king and court, nation and independence, for a people living under the thumb of foreign powers, the Torah might well be perceived as a path to identity and survival. And the living out of Torah in Torah Piety might be perceived as a means for God (and wisdom?) to dwell in the midst of the people and for the people to find a sense of meaning and order, an ethos, for their lives. Perhaps.

Did the postexilic community accomplish the task set out for them in the text of the Psalter? Did they flesh out, give breath to, stir the nephesh (the inmost being) of wisdom? Did the Psalter inspire Torah Piety and give life and future to the postexilic community? The fact that we are still wrestling with the text bears witness to the survival and future of our postexilic ancestors in the faith.

Have we accomplished the task? Have we fleshed out, given breath to, stirred the nephesh (the inmost being) of the poetic structure of the Psalter as Gerald Henry Wilson hinted that we might be able to do? With each musing, with each dialogue, with each movement of pen to paper, with each event of speaking, we continue to move closer. May the musings and the dialogues continue as we seek to understand these rich texts of which we are heirs. And in the words of Psalm 107, "Let the one who is wise heed these words and consider the steadfast love of the LORD".

\section{Consulted literature}

Childs, B S 1979. Introduction to the Old Testament as Scripture. Philadelphia: Fortress Press.

Crenshaw, J L 1981. Old Testament Wisdom: An Introduction. Atlanta: John Knox Press.

Ceresko, A R 1990. "The Sage in the Psalms", in The Sage in Israel and the Ancient Near East, ed. John G. Gammie and Leo G Perdue. Winona Lake, in: Eisenbrauns. 
Mann, T W 1988. The Book of the Torah: The Narrative Integrity of the Pentateuch. Atlanta: John Knox Press.

McCann, Jr., J C 1996. "The Book of Psalms: Introduction, Commentary, and Reflections", in The New Interpreter's Bible: A Commentary in Twelve Volumes, ed. Leander Keck, vol. IV Nashville: Abingdon Press.

Murphy, R E 1990. The Tree of Life: An Exploration of Biblical Wisdom Literature, 2d ed. Grand Rapids: Eerdmans Publishing.

O’Connor, K M 1988. The Wisdom Literature. Collegeville, MN: The Liturgical Press.

Wilson, G H 1985. The Editing of the Hebrew Psalter, SBL Dissertation Series, ed. J J M Roberts, vol. 76. Chico, CA: Scholars Press. 